НАУКОВИЙ ВІСНИК

Scientific messenger of Livi Natitinal University of
Veterinar Mediticie and Biotechnologies

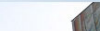

(⿻)

RIES: VETERINARY SCIEN
Науковий вісник Аьвівського національного університету ветеринарної медицини та біотехнологій імені С.3. Гжицького. Серія: Ветеринарні науки

Scientific Messenger of Lviv National University of Veterinary Medicine and Biotechnologies. Series: Veterinary sciences

UDC 619.616.98:579.887111:636.5

\title{
Bacterial contamination of chicken food egg with automated and manual sorting and packaging
}

\author{
D. V. Demyanenko ${ }^{1}$, Ye. V. Vashchyk ${ }^{2}$, T. I. Fotina ${ }^{1}$ \\ ${ }^{1}$ Sumy National Agrarian University, Sumy, Ukraine \\ ${ }^{2}$ National University of Pharmacy, Kharkiv, Ukraine
}

\section{Article info}

Received 14.09.2021

Received in revised form 18.10.2021

Accepted 19.10.2021

Sumy National Agrarian University, Herasyma Kondratieva Str., 160, Sumy, 40000, Ukraine.

National University of Pharmacy, Pushkinska str., 53, Kharkiv, 61002, Ukraine.

Tel.: +38-050-725-99-72 E-mail:sas03081978@gmail.com
Demyanenko, D. V., Vashchyk, Ye.V., \& Fotina, T. I. (2021). Bacterial contamination of chicken food egg with automated and manual sorting and packaging. Scientific Messenger of Lviv National University of Veterinary Medicine and Biotechnologies. Series: Veterinary sciences, 23(104), 3640. doi: $10.32718 /$ nvlvet10406

Chicken eggs are a staple food for humans and are consumed all over the world. Chicken eggs have a leading position among food products in terms of nutritional value and taste. During storage, under the influence of air oxygen and microorganisms, eggs deteriorate, contamination of opportunistic and pathogenic microflora increases. Purpose: analysis of the results of bacteriological studies of eggs of various producers during automatic and manual sorting and packaging from the trading network in Sumy and the Sumy region in accordance with DSTU 5028:2008 "Edible hen eggs. Specifications" and Microbiological Criteria for Establishing Food Safety Indicators. Materials and methods. Bacteriological studies of shell washings and egg contents were carried out according to standard methods. Samples of edible chicken eggs with automatic and manual sorting and packaging corresponded to DSTU 5028:2008, Microbiological criteria for establishing food safety indicators and BIE No. 5061-89. Pathogenic and opportunistic pathogens of bacterial diseases were not isolated from the surface of eggs of the control group during automated sorting and packing, spore bacteria of the genus Bacillus (Bacillus subtilis) were isolated. In washes from the egg shell surface with manual sorting and packaging, Streptococcus spp was found - $12 \%$ of the number of samples examined, E. faecalis - 34\%, P. aeruginosa - $11 \%$, and spore bacteria of the genus Bacillus (B. subtilis) - $43 \%$. The number of QMA\&OAMO and CGB (coli-forms) in both groups corresponded to the established norms, but the QMA\&OAMO indicator in the products of enterprises with manual collection and packaging was $34 \%$ higher compared to eggs from enterprises with automated sorting and packaging. Automation of the process of sorting and packing eggs provides the best microbiological indicators of the safety of edible hen eggs in comparison with those when using manual labor during sorting and packing. A complete transition to the automation of production processes for the production of edible eggs in Ukraine is required.

Key words: biosafety, egg production, Salmonella spp, S. aureus, P. aeruginosa.

\section{Бактеріальна контамінація курячого харчового яйця за автоматизованого та ручного сортування і пакування}

\author{
Д. В. Демяненко ${ }^{1}$, Є. В. Ващик ${ }^{2}$, Т. І. Фотіна ${ }^{1}$ \\ ${ }^{1}$ Сумський національний аграрний університет, м. Суми, Украӥна \\ ${ }^{2}$ Національний фармацевтичний університет, м. Харків, Украӥна
}

Курячі яйия є одним з основних продуктів харчування людини і споживаються в усьому світі. У процесі зберігання під дією кисню повітря і мікроорганізмів відбувається псування яєць, підвишується контамінація умовно-патогенною та патогенною мікрофлорою. Мета: аналіз результатів бактеріологічних досліджень яєць різних виробників за автоматизованого та ручного сортування і пакування з торгівельної мережі м. Сум та Сумської області відповідно до ДСТУ 5028:2008 “Яйця курячі харчові. Технічні 
умови” та Мікробіологічних критеріїв для встановлення показників безпечності харчових продуктів. Бактеріологічні дослідження змивів зі шкаралупи, вмісту яйчя проводили за стандартними методиками. Зразки яйця курячого харчового за автоматичного та ручного сортування і пакування відповідали ДСТУ 5028:2008, Мікробіологічним критеріям для встановлення показників безпечності харчових продуктів та МБВ № 5061-89. Та оскільки деякі країни СС, Ізраӥль, Саудівська Аравія під час складання договорів про експорт вимагають дослідження яєчної продукції з розширеним переліком патогенів, ми спрямували дослідження на індикачію головних збудників бактеріальних хвороб та харчових токсикоінфекцій. 3 поверхні яєць контрольної групи за автоматизованого сортування та пакування патогенних і умовно-патогенних збудників бактеріальних хвороб не виділено, ізольовано спорові бактеріі poду Bacillus (Bacillus subtilis). У змивах з поверхні шкаралупи яйця за ручного сортування та пакування виявлено Streptocоссиs spр. - $12 \%$ від числа досліджених проб, E. faecalis - $34 \%$, P. aeruginosa - $11 \%$ та cпорових бактерій poду Bacillus (B. subtilis) - $43 \%$. Кількість МАФАнМ та БГКП в обох групах відповідали встановленим нормам, але показник МАФАнМ у продукції підприємств з ручним збором та пакуванням на 34 \% вищий порівняно з яйцями від підприємств з автоматизованим сортуванням та пакуванням. Автоматизація процесу сортування та пакування яйця забезпечує краші мікробіологічні показники безпечності яйця курячого харчового порівняно із такими за застосування ручної праці під час сортування та пакування. Необхіднии повний перехід до автоматизацї виробничих процесів за виробництва харчового яйия в Украӥні.

Ключові слова: біобезпека, яєчне виробництво, Salmonella spp, S. aureus, P. aeruginosa.

\section{Вступ}

Курячі яйця за поживністю і смаковою якістю мають провідні позиції серед продуктів харчування (Eddin et al., 2019). Вони містять усі необхідні для життя поживні та біологічно активні речовини, які перебувають у легкозасвоюваній формі та в оптимальному співвідношенні. Яйце засвоюється організмом людини на 96-98 \% (Shcherbakova et al., 2015). Доброякісне куряче яйце за своєю поживністю еквівалентне приблизно 40 г м'яса і 120-150 г молока, забезпечує на 4-5 \% добову потребу дорослої людини в білках, жирах і мінеральних речовинах, амінокислотах та на 10-30 \% - в основних вітамінах (Tkachuk \& Lapa, 2012). Міжнародний досвід свідчить, що тільки завдяки зведенню проблеми якості на рівень національної ідеї можна не тільки перебороти економічну кризу, а й зайняти провідні позиції на світовому ринку (Dashkovskyy \& Salata, 2016). Останнім часом в нашій країні спостерігається інтенсивний розвиток птахівничої галузі. Сьогодні багато країн визнають проблему якості одним із пріоритетних напрямків своєї діяльності. Безпечність харчових продуктів пов'язана 3 наявністю небезпечних чинників у харчових продуктах на момент споживання (de Souza Sant'Ana, 2017; De Reu et al., 2005). Стурбованість щодо безпечності та якості харчових продуктів відчувається значною мірою в усьому світі.

Особливу біологічну небезпеку для здоров'я споживача несуть продукти тваринного походження, контаміновані такими мікроорганізмами як Salmonella spp, E. coli, S. aureus, P. aeruginosa та ін. Хвороби харчового походження, викликані мікробіологічними факторами ризику, становлять значну i зростаючу проблему суспільної охорони здоров'я (Fotina et al., 2014). Значним джерелом бактеріального обсіменіння харчових яєць у процесі їх виготовлення є низький санітарний стан приміщень, обладнання, апаратури, інвентарю та спецодягу робітників, який може бути забруднений мікрофлорою. Постає проблема визначення факторів, що впливають на санітарну якість та безпеку продуктів птахівництва; удосконалення системи ветеринарно-санітарного контролю та вивчення джерел бактеріального обсіменіння продуктів птахівництва (Mortimore, 2001; Fotina \& Kovalenko, 2012). Одним з визначальних факторів, що впливає на біобе- зпеку харчового яйця, $є$ автоматизація системи яйцезбору, сортування та пакування (De Reu et al., 2005; Jones et al., 2011). В Україні є птахогосподарства, в яких впроваджено автоматизовані системи сортування та пакування харчового яйця без участі людини (Triotec, Big Dutchman, Stalkaat, Sime-Tek, EXN 3000 i ORACION 6000), але в багатьох господарствах на даний час залишається ручне сортування та пакування.

Мета: аналіз результатів бактеріологічних досліджень яєць різних виробників за автоматизованого та ручного сортування і пакування з торговельної мережі м. Сум та Сумської області відповідно до ДСТУ 5028:2008 “Яйця курячі харчові. Технічні умови” та Мікробіологічних критеріїв для встановлення показників безпечності харчових продуктів.

\section{Матеріал і методи досліджень}

Дослідження проводили на базі кафедри ветсанекспертизи, мікробіології, зоогігієни та безпеки і якості продуктів тваринництва Сумського національного аграрного університету, Сумської регіональної державної лабораторії Держпродспоживслужби. Зразки для досліджень відбирали у роздрібній торговельній мережі м. Сум та Сумської області відповідно до Постанови КМУ від 14 червня 2002 р. N 833 "Про затвердження Порядку відбору зразків продукції тваринного, рослинного і біотехнологічного походження для проведення досліджень". Для цього в торговельній мережі м. Сум та Сумської області було закуплено яйце куряче столове від різних виробників. Досліджуваний матеріал розділено на 2 групи: по 6 зразків 3 партій яєць харчових курячих (по 30 яєць в кожному). Контрольна група - продукція від різних підприємств виробників з автоматизованим сортуванням та пакуванням, дослідна група - продукція виробництва підприємств $з$ ручним сортуванням та пакуванням. Зразки відбирали одночасно з подібною датою виробництва.

Змиви з поверхні шкаралупи яйця відбирали за допомогою стерильних аплікаторів “Волес". Бактеріологічні дослідження проводили за стандартними методиками з використанням поживних середовищ: гептадецилсульфатний агар, диференційний агар з діамантовим зеленим, середовище Ендо, лактозо- 
цистиновий агар, Мюллера-хінтона, бульйон Макконки, селенітовий агар, стрептоковий агар, стрептоковий бульйон, МПА, МПБ, бульйон Фразера, ПАЛКАМ агар, кров'яний агар, агар Крістенсена, середовище Фогеса-Проскауера для мікробіологічної диференціації ентеробактерій. Кількість МАФАнМ підраховували на універсальному лічильнику бактеріальних колоній. Приготовлені мазки з колоній фарбували за Грамом і мікроскопували (Yakubchak et al., 2005; Holovko et al., 2007).

\section{Результати та їх обговорення}

За вимогами ДСТУ 5028:2008 (Яйця курячі харчові. Технічні умови (33861), Мікробіологічним критеріям для встановлення показників безпечності харчових продуктів (затв. 19.07.2012 № 548) та МБВ
№ 5061-89, мікробіологічними показниками якості та безпеки харчових яєць є МАФАнМ (КУО/г), БГКП (г), патогенні мікроорганізми, в т. ч. роду Salmonella. Але оскільки деякі країни ЄС, Ізраїль, Саудівська Аравія та ін. під час складання договорів про експорт вимагають дослідження яєць, яєчної продукції за розширеним переліком патогенів, ми спрямували дослідження на індикацію головних збудників бактеріальних хвороб та харчових токсикоінфекцій.

В результаті бактеріологічних досліджень зразків яйця курячого харчового контрольної групи 3 підприємств виробників 3 повністю автоматизованим сортуванням та пакуванням патогенних та умовнопатогенних збудників бактеріальних хвороб не виділено, ізольовано спорові бактерії роду Bacillus (Bacillus subtilis) (табл. 1).

Таблиця 1

Бактеріологічне дослідження яйця курячого харчового за автоматизованого та ручного сортування і пакування

\begin{tabular}{|c|c|c|c|c|}
\hline \multirow{2}{*}{ Показники/ об'єкт } & \multicolumn{2}{|c|}{$\begin{array}{c}\text { Харчове яйце за автоматизованого сортування } \\
\text { та пакування } \\
\end{array}$} & \multicolumn{2}{|c|}{$\begin{array}{c}\text { Харчове яйце за ручного сортування та } \\
\text { пакування }\end{array}$} \\
\hline & змиви з поверхні & $\begin{array}{l}\text { внутрішній вміст } \\
\text { (жовтки) }\end{array}$ & змиви 3 поверхні & $\begin{array}{l}\text { внутрішній вміст } \\
\text { (жовтки) }\end{array}$ \\
\hline $\begin{array}{l}\text { МАФАнМ } \\
(\text { КУО/г), } \mathrm{M} \pm \mathrm{m}\end{array}$ & & $2,39 \times 10^{3} \pm 0,02 \times 10^{3}$ & & $3,2 \times 10^{3} \pm 0,02 \times 10^{3 *}$ \\
\hline БГКП (г) & & не виявлено & & не виявлено \\
\hline Salmonella spp. & - & - & - & - \\
\hline E. coli & - & - & - & - \\
\hline S. aureus & - & - & - & - \\
\hline P. aeruginosa & - & - & + & - \\
\hline Streptococcus spp. & - & - & + & - \\
\hline Bacillus spp. & $\begin{array}{c}+ \\
\text { B. subtilis }\end{array}$ & - & $\begin{array}{c}+ \\
\text { B. subtilis }\end{array}$ & - \\
\hline Enterococcus spp. & - & - & $\stackrel{+}{\text { E. faecalis }}$ & - \\
\hline Proteus spp. & - & - & - & - \\
\hline Staphylococcus spp. & - & - & - & - \\
\hline L. monocytogenes & - & - & - & - \\
\hline Clostridium spp. & - & - & - & - \\
\hline
\end{tabular}

Примітка: ступінь вірогідності до контролю : *-P <0,05

Дані таблиці 1 свідчать, що яйце контрольної групи 3 підприємств із автоматизованим сортуванням та пакуванням за мікробіологічними показниками відповідає ДСТУ 5028:2008 (Яйця курячі харчові. Технічні умови (33861), Мікробіологічним критеріям для встановлення показників безпечності харчових продуктів (затв. 19.07.2012 № 548) та МБВ № 5061-89. Показники МАФАнМ та БГКП відповідають встановленим нормативним показникам.

Аналіз результатів випробувань продукції дослідної групи показує, що зразки курячого харчового яйця 3 птахофабрик з ручним сортуванням та пакуванням за мікробіологічними показниками теж відповідають ДСТУ 5028:2008, Мікробіологічним критеріям для встановлення показників безпечності харчових продуктів та МБВ № 5061-89. Кількість МАФАнМ та БГКП відповідають встановленим нормам, але показник МАФАнМ в продукції підприємств 3 ручним збором та пакуванням на $34 \%$ вищий порівняно 3 яйцями від підприємств з автоматизованим сортуванням та пакуванням.

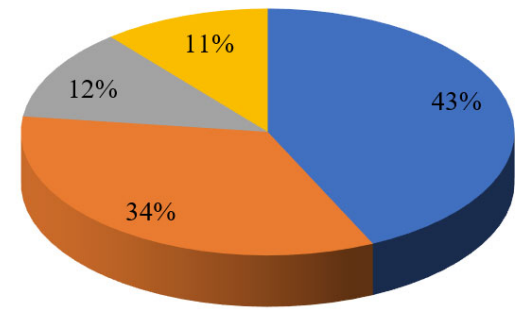

B. subtilis $\square$ E. faecalis $\square$ Streptococcus spp. $\square$ P. aeruginosa

Рис. 1. Спектр ізольованої мікрофлори з поверхні шкаралупи яйця

До того ж наявність у змивах з поверхні шкаралупи яйця Streptococcus spp. - 12 \% від числа досліджених проб, E. faecalis - 34 \%, P. Aeruginosa - $11 \%$ та спорових бактерій роду Bacillus (B. subtilis) - 43 \% свідчить 
про порушення санітарно-гігієнічних вимог за сортування, транспортування та зберігання харчового курячого яйця, порушення температурного режиму та вологості повітря у торговельних точках (рис. 1).

Аналіз результатів органолептичних досліджень, наведених у таблиці 2, свідчить, що такі показники, як пошкодженість, забрудненість, наявність в яйці включень (плям), розташування повітряної камери та іiі рухливості; стан, положення і рухливість жовтка; стан, консистенція та прозорість білка не мали суттєвих відмінностей в продукції з підприємств із автоматизованим та ручним сортуванням і пакуванням.

\section{Таблиця 2}

Органолептичні дослідження яйця курячого харчового з підприємств із автоматизованим та ручним сортуванням і пакуванням

\begin{tabular}{clll}
\hline $\begin{array}{c}\text { № } \\
\text { групи }\end{array}$ & \multicolumn{1}{c}{ Положення жовтка } & \multicolumn{1}{c}{ Стан білка } & \multicolumn{1}{c}{ Стан шкаралупи } \\
\hline \multirow{2}{*}{$\begin{array}{l}\text { Ледь видимий під час овоскопії, контури не } \\
\text { окреслені, займає центральне положення, } \\
\text { малорухливий під час обертання яйця }\end{array}$} & $\begin{array}{l}\text { Чистий, щільний, } \\
\text { світлий, прозорий, без } \\
\text { сторонніх включень }\end{array}$ & $\begin{array}{l}\text { Чиста, непошкоджена, без видимих змін } \\
\text { структури, без слідів крові і посліду }\end{array}$ \\
\hline $\begin{array}{l}\text { Ледь видимий під час овоскопії, контури не } \\
\text { окреслені, займає центральне положення, } \\
\text { злегка рухливий під час обертання яйця }\end{array}$ & $\begin{array}{l}\text { Чистий, щільний, } \\
\text { світлй, прозорий, без } \\
\text { сторонніх включень }\end{array}$ & $\begin{array}{l}\text { Чиста, непошкоджена, без видимих змін } \\
\text { струкури, наявні поодинокі плями та } \\
\text { смуги від транспортерної стрічки }\end{array}$ \\
\hline
\end{tabular}

За результатами органолептичних досліджень яйця 3 підприємств із ручним та автоматизованим сортуванням і пакуванням відповідають нормативним показникам, встановленим у ДСТУ 5028:2008 (Яйця курячі харчові. Технічні умови (33861).

Підсумовуючи, зазначимо, що автоматизація процесу сортування та пакування яйця забезпечує кращі мікробіологічні показники безпечності яйця курячого харчового порівняно із такими за застосування ручної праці під час сортування та пакування. Як свідчать наукові джерела, в сучасних умовах основним джерелом обсіменіння поверхні яйця мікрофлорою можна назвати порушення ветеринарно-санітарних вимог за технологічного процесу виробництва, недотримання правил особистої гігієни персоналу (Mallet et al., 2006). Автоматизація процесу сортування та пакування мінімізує участь людини, що зменшує ризик контамінації продукції (Smith et al., 2000). До того ж модернізовані автоматизовані системи сортування та пакування, наприклад CANOPUS виробництва NABEL, містять УФ-опромінювачі для дезінфекції яєць, що значно зменшує бактеріальну контамінацію яєць.

У світі зараз актуальним є питання щодо тривалого зберігання харчового яйця 3 гарантованими характеристиками якості та безпечності. Якщо технологічні режими зберігання давно увійшли до світових стандартів, то питання санітарної обробки яєць перед зберіганням залишається дискусійним. Національний стандарт на харчові курячі яйця обмежує зберігання в холодильнику митих яєць до 12 діб, тимчасом як в Сполучених Штатах Америки, Австралії, Японії миття курячих яєць перед зберіганням визнано обов'язковою процедурою (Shevchik et al., 2019).

\section{Висновки}

Спектр бактеріальної мікрофлори шкаралупи харчового яйця різних торгових марок виробників з ручним сортуванням та пакуванням 3 торгової мережі Сумської області представлений переважно мікроорганізмами: Streptococcus spp. - 12 \% від числа дослі- джених проб, E. faecalis - $34 \%$, P. aeruginosa - $11 \%$ та спорових бактерій роду Bacillus (B. subtilis) - $43 \%$. 3 поверхні яйця за автоматичного сортування та пакування ізольовано тільки B. subtilis. Акцентуємо увагу на розширенні переліку патогенів для бактеріологічного контролю безпеки яйця харчового. Зразки яйця курячого харчового за автоматичного та ручного сортування та пакування відповідали регламентуючій нормативній документації, але показник МАФАнМ в продукції підприємств 3 автоматизованим сортуванням та пакуванням на 34 \% нижчий порівняно з таким за умов ручного сортування та пакування. Підтверджено, що автоматичне сортування та пакування яйця $\epsilon$ одним зі значущих факторів забезпечення бактеріальної біобезпеки харчового яйця, забезпечує кращі мікробіологічні показники безпечності яйця курячого харчового порівняно з такими за застосування ручної праці під час сортування та пакування. Необхідний повний перехід до автоматизації виробничих процесів за виробництва харчового яйця в Україні.

Перспективою подальших досліджень є вивчення способів зменшення ризиків контамінації харчового яйця умовно-патогенною мікрофлорою: пошук екологічно безпечних нейтральних сполук для обробки харчових яєць.

\section{Відомості про конфлікт інтересів}

Автори стверджують про відсутність конфлікту інтересів.

\section{References}

Dashkovskyy, O., \& Salata, V. (2016). Hazard analysis and critical control points (HACCP), the production of meat sausages on p.c. "Stryjsky meats delicious". Scientific Messenger LNUVMBT named after S. Z. Gzhytskyj, 18(3(70)), 83-87. doi: 10.15421/nvlvet7019.

De Reu, K., Grijspeerdt, K., Heyndrickx, M., Uyttendaele, M., \& Herman, L. (2005). The use of total aerobic and Gram-negative flora for quality assurance in the production chain of consumption eggs. Food Control, 16(2), 147-155. doi: 10.1016/j.foodcont.2004.01.004. 
De Reu, K., Grijspeerdt, K., Heyndrickx, M., Uyttendaele, M., Debevere, J., \& Herman, L. (2006). Bacterial shell contamination in the egg collection chains of different housing systems for laying hens. Br. Poult. Sci, 47(2), 163-172. doi: 10.1080/00071660600610773.

de Souza Sant'Ana, A. (2017). Quantitative Microbiology in Food Processing: Modeling the Microbial Ecology. John Wiley \& Sons, Ltd. doi: 10.1002/9781118823071.

Eddin A. S., Ibrahim, S. A., \& Tahergorabi, R. (2019). Egg quality and safety with an overview of edible coating application for egg preservation United States Food Chemistry, 296, 29-39. doi: 10.1016/j.foodchem.2019.05.182.

Fotina, T. I., Kasianenko, O. I., Fotina, H. A., \& Dvorska, Yu. E. (2014). Epizootolohichne ta epidemiolohichni znachennia kharchovykh bakterialnykh patoheniv. Naukovo-tekhnichnyi biuleten Instytutu biolohii tvaryn i Derzhavnoho naukovo-doslidnoho kontrolnoho instytutu vetpreparativ ta kormovykh dobavok, 15(2-3), 141-148 (in Ukrainian).

Fotina, T.I., \& Kovalenko, A. V. (2012). Yakist produktiv ptakhivnytstva ta systema NASSR. Visnyk Sumskoho natsionalnoho ahrarnoho universytetu. Veterynarna medytsyna, 1, 44-49 (in Ukrainian).

Holovko, A. N., Ushkalov, V. A., Skripnyk, V. H., \& Stehnyi, B. T. (2007). Mykrobyolohycheskye y vyrusolohycheskye metody yssledovanyia $\mathrm{v}$ veterynarnoi medytsyne: spravochnoe posobye. Kh.: "NTMT" (in Russian).

Jones, D, Anderson, Kenneth, \& Musgrove, M. (2011). Comparison of environmental and egg microbiology associated with conventional and free-range laying hen management. Poultry science, 90(9), 2063-2068. doi: $10.3382 / \mathrm{ps} .2010-01139$.

Mallet, S., Guesdon, V., Ahmed, A. M. H., \& Nys, Y. (2006). Comparison of eggshell hygiene in two housing systems: Standard and furnished cages. Br. Poult. Sci, 47(1), 30-35. doi: 10.1080/00071660500468132.

Mortimore, S. (2001). How to make HACCP really work in practice. Food Control, 12(4), 209-215. doi: 10.1016/S0956-7135(01)00017-2.

Shcherbakova, N. S., Peredera, Zh. O., \& Peredera, S. B. (2015). Vyznachennia yakosti kuriachykh yaiets vyrobnytstva PAT "Poltavska ptakhofabryka". Visnyk Poltavskoi derzhavnoi ahrarnoi akademii, 4, 61-63 (in Ukrainian).

Shevchik, R. S., Kuneva, L. V., \& Samoyluk, G. V. (2019). Vplyv sposobiv obrobky ta zberihannia na yakisni pokaznyky kharchovykh kuriachykh yaiets. Theoretical and Applied Veterinary Medicine, 7(2), 69-73. doi: 10.32819/2019.71012 (in Ukrainian).

Smith, A., Rose, S. P., Wells, R. G., \& Pirgozliev, V. (2000). The effect of changing the excreta moisture of caged laying hens on the excreta and microbial contamination of their egg shells. British Poultry Science, 41(2), 168-173. doi: 10.1080/713654903.

Tkachuk, A., \& Lapa, O. I. (2012). Pokazniki yakosti ta bezpechnosti kharchovih yayets, 7(36). URL: https://nd.nubip.edu.ua/2012_7/12koy.pdf(in Ukrainian).

Yakubchak, O. M., Khomenko, V. I., \& Kovalenko, V. L. (2005). Rekomendatsii shchodo sanitarnomikrobiolohichnoho doslidzhennia zmyviv $\mathrm{Z}$ poverkhon test-obiektiv ta obiektiv veterynarnoho nahliadu i kontroliu. metodychni rekomendatsii. Kyiv (in Ukrainian). 